\title{
STUDI EUTROFIKASI AKIBAT AKTIVITAS PENGGUNAAN LAHAN DI DANAU BUYAN
}

\author{
Ida Bagus Ketut Gede Kertia ${ }^{1 *}$, I Wayan Arthana ${ }^{2)}$, I Wayan Sandi Adnyana ${ }^{3)}$ \\ ${ }^{1)}$ Program Magister Ilmu Lingkungan Universitas Udayana \\ ${ }^{2}$ Fakultas Kelautan dan Perikanan Universitas Udayana \\ ${ }^{3)}$ Fakultas Pertanian Universitas Udayana \\ *Email: idabaguskertia@ymail.com
}

\begin{abstract}
Increased in land use activity in Buyan Lake catchment area can be a threat to multifunction of the lake. Identification the impact due to land use activity is to important of lake management. This study aims to know the land use and its activities, predicted the yield of sediment and nutrient losses, and knew of trophic state for the lake. The Lake Buyan catchment area is 1,943.8 ha. This research use survey method and in situ and ex situ measurement from March to May 2017. Type of data collected were land use and its activities, C-organic and soil nutrient, and variables of trophic state for the lake.This study showed that dryland vegetables crops with bench terrace by low standard contruction, shrub with grass, and coffee plantation with traditional terrace with area each of 71.9 ha (3.7\%), 43.0 ha $(2.2 \%)$, and 25.4 ha $(1.3 \%)$ respectively has an erosion of higher than tolerable soil loss. The sediment yield and C-organic, nitrogen, phosphate and potassium losses with the amount each of 9,399.4, 266.6, 14.5, 15.8, and 58.7 ton year-1 respectively, and with soil and water conservation practices is very effective to reduced the sediment yield and C-organic, nitrogen, phosphate and potassium losses with the amount each of $3,160.1,89.6,4.9,5.3$, and 19.7 ton year-1. Average of nitrogen, phosphate, chlorophyll a, and tranparency with the value each of 3,500, 118.4, 48.2 $\mu \mathrm{g} \mathrm{L}-1$ and $1.8 \mathrm{~m}$ showed that trophic state for Buyan Lake is euthrophic until hypereuthrophic, and a moderate euthrophic indicated from the average TSI with the value of 64.3.
\end{abstract}

Keywords: Buyan Lake, land use, erosion, sediment yield, eutrophic

\section{PENDAHULUAN}

Peningkatan kegiatan manusia di daerah tangkapan air (DTA) dalam banyak kasus adalah penyebab kerusakan ekosistem danau. Dalam upaya pemenuhan kebutuhan hidup yang terus meningkat cenderung mendorong terjadinya pemanfaatan sumberdaya alam yang eksploitatif terutama terhadap penggunaan lahan.

Penggunaan lahan dan aktivitasnyadiDTA danau yang tidak mengikuti kaidah konservasi tanah adalah penyebab terjadinya peningkatan erosi lahan (Kementerian Lingkungan Hidup, 2008).Subehi, et al. (2014) menyatakan bahwa telah terjadi penurunan kualitas lingkungan DTA dan perairan Danau Buyan sebagai akibat penggunaan lahan dan kegiatan penggunaan lahan di DTA Danau Buyan.Danau Buyan adalah salah satu danau alam di Provinsi Bali yang telah mengalami pendangkalan dan pertumbuhan tumbuhan air yang sangat cepat. Aktivitas penggunaan lahan pada DTA Danau Buyan dapat diduga menjadi faktor penyebabnya. Sebagai 
hasil erosi, masuknya partikel-partikel tanah dan hara yang mencapai perairan diduga sebagai pemicu peningkatan kesuburan perairan.

Dalam Gerakan Danau Bersih (Gerdasih) Lestari Tahun 2015 yang bertemakan "Satukan Langkah, Lindungi Ekosistem Danau, Demi Kelangsungan Hidup Anak Cucu Kita" Kepala Badan Lingkungan Hidup Provinsi Bali menyatakan bahwa Danau Buyan terindikasi dalam kondisi kritis. Pendangkalan perairan dan pertumbuhan tumbuhan air yang berlebih dapat menjadi ancaman serius terhadap kelestarian Danau Buyan (Biro Humas Sekretariat Provinsi Bali, 2015).

Penetapan status kritis suatu danau dan pengelolaan danau secara terpadu dan holistik merupakan strategi yang sangat diperlukan untuk menciptakan keberlanjutan sumberdaya danau. Oleh sebab itu, dipandang perlu dilakukan studiuntuk menentukan penggunaan lahan dan aktivitasnya yang berkontribusi terhadap hasil sedimen dan kehilangan hara DTA, dan peningkatan kesuburan perairan Danau Buyan. Hasil studi ini diharapkan dapat dijadikan sebagai dasar pertimbangan dalam mendapatkan strategi pencegahan degradasi dan pemulihan ekosistem Danau Buyan yang tepat sehingga pengelolaan danau dapat lebih terencana, hasilnya dapat diperkirakan, dan berkelanjutan.

\section{METODOLOGI}

Penelitian ini dilakukan dengan metode survei dan pengukuran in situdanex situ pada bulan Maret-Mei 2017. Jenis data yang dikumpulkan berupa penggunaan lahan dan aktivitasnya melalui wawancara dengan daftar pertanyaan, wawancara mendalam, dan pengamatan secara fisik; kandungan C-organik dan hara tanah melalui uji laboratorium terhadap sampel tanah; dan kandungan variabel status trofik perairan danau melalui uji laboratorium terhadap sampel air.

Evaluasi terhadap penggunaan lahan dan aktivitasnya mempertimbangkan satuan unit lahan DTA Danau Buyan, erosi aktual sesuai hasil penelitian Adnyana (2006), hasil sedimen dihitung menurut SCS National Engineering Handbook (DPMA, 1984 dalam Asdak, 1995), kehilangan hara diprediksi dengan mengkonversi kandungan $\mathrm{C}$ organik dan hara tanah terhadap hasil sedimen, dan status trofik danau menurut kriteria Peraturan Menteri Lingkungan Hidup Nomor 28 tahun 2009 dan indeks status trofik (TSI) Carlson (1977).

Hasil sedimen menurut SCS National Engineering Handbook (DPMA, 1984 dalam Asdak, 1995) ditetapkan dengan persamaan :

$$
\mathrm{Y}=\mathrm{E}(\mathrm{SDR}) \mathrm{Ws}
$$

$$
\begin{gathered}
\text { dimana } \mathrm{Y}=\text { hasil } \\
\mathrm{E}=\quad \begin{array}{l}
\text { sedimen per } \\
\text { satuan luas } \\
\text { (ton/tahun), } \\
\text { erosi total } \\
\text { (ton/ha/tahun) }
\end{array} \\
\mathrm{SDR}=\text { Sediment } \\
\text { Delivery } \\
\text { Ratio (nisbah } \\
\text { pelepasan } \\
\text { sedimen), dan }
\end{gathered}
$$

SDR diprediksi Boyce (1975) dengan menggunakan persamaan :

$$
\begin{aligned}
& \mathrm{SDR}=0,14 \mathrm{~A}^{0,3} \\
& \operatorname{dimanaA}=\text { luas DTA }\left(\mathrm{km}^{2}\right) .
\end{aligned}
$$


Kehilangan hara dihitung dengan mengkonversikan kandungan hara tanah hasil analisis laboratorium dengan persamaan:

$$
\begin{aligned}
& \mathrm{K}_{h}=\mathrm{Y} \times \mathrm{H} \\
& \text { dimana } \quad \mathrm{K}_{h}=\text { kehilangan C- } \\
& \text { organik dan hara tanah } \\
& \text { (ton/tahun), } \\
& \mathrm{Y}=\text { hasil sedimen } \\
& \text { (ton/tahun), } \\
& \text { dan } \\
& \mathrm{H}=\text { kandunganC }- \\
& \text { organik } \\
& \text { dan hara } \\
& \operatorname{tanah}(\%) \text {. }
\end{aligned}
$$

TSI ditetapkan dengan persamaan:

$$
\begin{aligned}
\text { TSI-P } & =14,41 \times \operatorname{Ln}(\mathrm{TP})+4,15 \\
\text { TSI-C } & =30,6+9,81 \times \text { Ln }(\text { Chlor-a }) \\
\text { TSI-S } & =60 \times 14,41 \times \text { Ln }(\text { Secchi }) \\
\text { TSI } & =(\text { TSI-P }+ \text { TSI-C }+ \text { TSI-S }): 3
\end{aligned}
$$$$
\text { dimana TSI-P (nilai indeks total }
$$$$
\text { fosfat), TSI-C (nilai }
$$
indeks klorofil a), TSI-S (nilai indeks kecerahan), TP (total fosfat), Chlor-a (klorofil), dan Secchi (kecerahan).

\section{HASIL DAN PEMBAHASAN}

\subsection{Penggunaan Lahan dan Aktivitasnya}

Penggunaan lahan menurut unit lahan di lokasi penelitian didominasi hutan dengan serasah sedang seluas $1.363,3$ ha $(70,14 \%)$ dan paling kecil adalah pertanaman kopi seluas 25,4 ha $(1,3 \%)$. Penggunaan lahan lainnya berupa budidaya sayur mayur lahan kering seluas 512,1 ha $(26,4 \%)$ dan semak belukar seluas 43,0 ha $(2,2 \%)$ (Adnyana, 2006 dan hasil analisis) seperti Tabel 1.

Aktivitas penggunaan lahan di lokasi penelitian seperti Tabel 2. Budidaya sayur mayur lahan kering dengan pengolahan tanah yang masih konvensional (olah tanah sempurna), penanaman pada petak teras bangku searah lereng pada musim hujan, penggunaan mulsa plastik, penggunaan pupuk, pestisida, dan insektisida anorganik yang masih relatif tinggi, dan pengelolaan sisa tanaman yang belum memenuhi kaidah konservasi tanah dan air merupakan aktivitas penggunaan lahan dapat diduga berdampak penting terhadap degradasi lahan dan eutrofikasi.

Jenis tanah di lokasi penelitian adalah andosol dan regosolseperti Tabel 1tergolong peka sampai sangat peka terhadap erosi. Tanpa tindakan konservasi yang memadai, dapat dipastikan terjadi peristiwa erosi yang berpotensi menimbulkan degradasi lahan. Pengolahan tanah di lokasi penelitian dapat diduga sebagai salah satu penyebab terjadinya percepatan degradasi lahan. Ariska et al. (2016) menyatakan bahwa perlakuan tanpa olah tanah dan pemakaian mulsa jagung 6 ton/ha pada pertanaman kedelai di lahan kering kebun percobaan Taman Bogo, masam Lampung Timur memiliki kemampuan meretensi air 1,3 kali lebih besar dibandingkan perlakuan olah tanah konvensional tanpa mulsa. Pori air tersedia pada perlakuan tanpa olah tanah dan pemakaian mulsa jagung 6 ton/ha sebesar $10,4 \%$ dan olah tanah konvensional tanpa mulsa sebesar $8,1 \%$. 
Tabel 1.Penggunaan Lahan di Lokasi Penelitian

\begin{tabular}{rrlcrrr}
\hline \multirow{2}{*}{ No. } & Unit & \multicolumn{1}{c}{ Penggunaan lahan } & Kemiringan & Jenis & \multicolumn{2}{c}{ Luas } \\
\cline { 6 - 7 } & lahan & & lereng $(\boldsymbol{\%})$ & tanah & \multicolumn{1}{c}{ ha } & \% \\
\hline 1 & 2 & Budidaya sayur mayur lahan kering & 2 & Regosol & 171,7 & 8,8 \\
2 & 3 & Budidaya sayur mayur lahan kering & 3 & Andosol & 5,8 & 0,3 \\
3 & 4 & Budidaya sayur mayur lahan kering & 4 & Regosol & 243,6 & 12,5 \\
4 & 5 & Budidaya sayur mayur lahan kering & 12 & Andosol & 19,2 & 1,0 \\
5 & 6 & Budidaya sayur mayur lahan kering & 12 & Regosol & 28,6 & 1,5 \\
6 & 8 & Budidaya sayur mayur lahan kering & 23 & Regosol & 19,9 & 1,0 \\
7 & 10 & Budidaya sayur mayur lahan kering & 36 & Regosol & 23,4 & 1,2 \\
8 & 11 & Pertanaman kopi & 28 & Regosol & 25,4 & 1,3 \\
9 & 13 & Semak belukar & 6 & Regosol & 30,0 & 1,5 \\
10 & 14 & Semak belukar & 9 & Regosol & 13,0 & 0,7 \\
11 & 16 & Hutan dengan serasah rendah & 5 & Regosol & 23,6 & 1,2 \\
12 & 19 & Hutan dengan serasah rendah & 23 & Andosol & 8,5 & 0,4 \\
13 & 20 & Hutan dengan serasah rendah & 21 & Regosol & 82,5 & 4,2 \\
14 & 21 & Hutan dengan serasah rendah & 39 & Andosol & 94,4 & 4,9 \\
15 & 22 & Hutan dengan serasah rendah & 41 & Regosol & 41,2 & 2,1 \\
16 & 23 & Hutan dengan serasah rendah & 58 & Andosol & 216,9 & 11,2 \\
17 & 24 & Hutan dengan serasah rendah & 60 & Regosol & 36,9 & 1,9 \\
18 & 25 & Hutan dengan serasah rendah & 80 & Regosol & 859,4 & 44,2 \\
\hline
\end{tabular}

Sumber:Adnyana (2006) dan hasil analisis

Dilihat dari Tabel 2, penutup tanah yang digunakan di lokasi penelitian adalah mulsa plastik. Mulsa plastik kurang layak direkomendasikan sebagai salah satu teknik konservasi sumberdaya lahan dan air. Aliran permukaan pada pemakaian mulsa plastik cenderung lebih tinggi dibandingkan tanpa mulsa (Adnyana, 2005 dalam Adnyana, 2009 dan Faizal, et al., 2013).

Efektivitas penggunaan insektisida dan pestisida anorganik dalam pengendalian hama dan penyakit di lokasi penelitian menjadi hambatan dalam upaya menekan penggunaan insektisida dan pestisida anorganik. Seperti Tabel 2, pengunaan penggunaan insektisida dan pestisida tidak dapat terelakkan, dan yang perlu dilakukan adalah upaya mengurangi dampak negatif penggunaan pestisida terhadap lingkungan dan manusia.Pada penelitian pestisida klor-organik dalam air Danau Buyan Buleleng Bali, terdeteksi sebesar 5,02 ppb residu cemaran DTT dan 1,99 ppb residu cemaran klorotalonil terkandung dalam air Danau Buyan (Manuaba, 2007).

Pengelolaan bekas tanaman seperti Tabel 2 menunjukkan bahwa tindakan tersebut diyakini dapat mempertahankan kualitas sifat-sifat tanah untuk menunjang kegiatan pertanian secara berkelanjutan. Tindakan konservasi ini belum layak direkomendasikan sebagai salah satu teknik konservasi sumberdaya lahan dan air yang memadai karena keterbatasan penelitian yang berkaitan dengan efektivitas pemanfaatan sisa tanaman langsung ke tanah seperti dilakukan petani di lokasi penelitian. Penelitian yang dapat dijumpai adalah berkaitan dengan efektivitas pemanfaatan sisa tanaman sebagai mulsa. Erosi dan aliran permukaan sangat efektif ditekan dengan penggunaan sisa tanaman sebagai mulsa (Heryani et al., 2013 dan Ariska et al., 2016). 
Tabel 2. Aktivitas penggunaan lahan di lokasi penelitian

\begin{tabular}{|c|c|c|}
\hline No. & Teknik budidaya & Aktivitas responden \\
\hline \multirow[t]{5}{*}{1} & Pengolahan tanah & \\
\hline & Teknik pengolahan tanah & olah tanah sempurna \\
\hline & Lama pengolahan tanah & $23,8-25,0$ hari/ha \\
\hline & Teknik konservasi tanah & a) teras bangku buruk sampai sedang \\
\hline & & $\begin{array}{l}\text { b) pada petak teras bangku dibuat guludan disesuaikan } \\
\text { dengan musim tanam (searah lereng pada musim hujan dan } \\
\text { searah kontur pada musim kemarau), dan sejajar bidang } \\
\text { lahan garapan terpanjang }\end{array}$ \\
\hline \multirow[t]{5}{*}{2} & Komoditi & \\
\hline & Metode penanaman & $\begin{array}{l}\text { a) budidaya sayur mayur secara monokultur, dan penanaman } \\
\text { dalam guludan pada petak teras bangku untuk budidaya } \\
\text { sayur mayur }\end{array}$ \\
\hline & & b) pertanaman kopi tanpa tindakan konservasi \\
\hline & $\begin{array}{l}\text { Umur panen (hari setelah } \\
\text { tanam) }\end{array}$ & $\begin{array}{l}\text { a) tomat (60-100), kubis dan brokolo (80-110), kentang (80- } \\
\text { 120), wortel (90-120), paprika (150-360), dan stroberi } \\
(150-540)\end{array}$ \\
\hline & & b) kopi arabika (2-2,5 tahun) dan robusta (2,5-3 tahun) \\
\hline \multirow[t]{3}{*}{3} & Penutup tanah & \\
\hline & Jenis & $\begin{array}{l}\text { mulsa plastik, warna hitam pada musim hujan dan putih pada } \\
\text { musim kemarau, pemberian atap dari plastik putih bening untuk } \\
\text { beberapa komoditi, dan antar guludan berupa tanah terbuka } \\
\text { dengan jarak } 20-25 \mathrm{~cm}\end{array}$ \\
\hline & Waktu pengaplikasian & $\begin{array}{l}\text { pemasangan mulsa dilakukan langsung setelah pembuatan } \\
\text { guludan selesai, sedangkan pemberian atap dilakukan } 7-14 \text { hari } \\
\text { setelah untuk tanam non cabai, paprika, dan tomat }\end{array}$ \\
\hline \multirow[t]{4}{*}{4} & Pemupukan & \\
\hline & Waktu pemberian pupuk & $\begin{array}{l}\text { pengolahan tanah/pupuk dasar dan pupuk susulan sebulan } \\
\text { setelah tanam untuk kubis, brokoli, wortel, dan kentang, dan } \\
\text { fase pertengahan dan generatif untuk paprika dan stroberi. }\end{array}$ \\
\hline & Dosis & $\begin{array}{l}\text { a) pupuk dasar : pupuk kandang (10-15 ton/ha), urea (100-150 } \\
\mathrm{kg} / \mathrm{ha}) \text {, TSP } 200-300 \mathrm{~kg} / \mathrm{ha} \text {, dan KCL (100-150 kg/ha) }\end{array}$ \\
\hline & & $\begin{array}{l}\text { b) pupuk susulan : campuran urea dan KCL (250-300 kg } \\
\text { dengan perbandingan 2:1 atau 3:1), fase pertengahan ( NPK } \\
\text { seimbang 20:20:20 atau NPK 10-10-10), dan fase generatif } \\
\text { (NPK berkadar N dan K 1:2 atau 1:3) }\end{array}$ \\
\hline \multirow[t]{4}{*}{5} & Penyiraman & \\
\hline & Frekuensi & 2-3 hari/minggu \\
\hline & Sumber air & $\begin{array}{l}\text { a) air danau (untuk daerah dekat danau disedot pompa, dan } \\
\text { daerah dataran tinggi disedot pompa dan dibuatkan } \\
\text { penampungan) }\end{array}$ \\
\hline & & $\begin{array}{l}\text { b) air hujan (dibuatkan sejenis kolam sebagai penampung air } \\
\text { hujan) }\end{array}$ \\
\hline \multirow[t]{3}{*}{6} & Waktu pengaplikasian & situasi dan kondisi pertanaman \\
\hline & Jenis insektisida & $\begin{array}{l}\text { Mestafen } 200 \text { EC, Kaliandra } 482 \text { EC, Rodamec } 18 \text { EC, } \\
\text { Meothrin } 50 \text { EC, Dupont Lannate } 40 \text { SP, Metindo } 25 \text { WP, } \\
\text { Dobeldor } 50 \text { EC, Decis } 25 \text { EC, Pounce } 20 \text { EC, Callicron } 500 \\
\text { EC, Regent } 50 \text { SC, Bamex } 18 \text { EC, Dursban } 200 \text { EC, } \\
\text { Termiban } 400 \text { EC, Pegasus } 500 \text { EC, Sidamethrin } 50 \text { EC, Cronus } \\
18 \text { EC, dan Kontan } 500 \text { EC. }\end{array}$ \\
\hline & Jenis pestisida & $\begin{array}{l}\text { Acrobat } 50 \text { WP, Score } 250 \text { EC, Trobintop } 250 \text { SC, Cabrio } 250 \\
\text { EC, Masalgin } 50 \text { WP, Sorento } 250 \text { EC, Carino } 250 \text { EC, Nordox } \\
56 \text { WP, dan Amistar Top } 325 \text { SC }\end{array}$ \\
\hline 7 & Pengelolaan bekas tanaman & $\begin{array}{l}\text { a) dibiarkan mengering dan dibenamkan ke tanah saat } \\
\text { pengolahan tanah } \\
\text { b) dibiarkan mengering dan dibakar }\end{array}$ \\
\hline
\end{tabular}

Sumber: hasil analisis 


\subsection{Hasil Sedimen dan Kehilangan Hara}

Erosi yang terjadi di lokasi penelitian yaitu dari 2,1 ton/ha/tahun sampai dengan 670,3 ton/ha/tahun seperti Tabel 3. Erosi terkecil sebesar 2,1 ton/ha/tahun terjadi pada unit lahan 20 (hutan dengan serasah rendah) dan erosi terbesar sebesar 670,3 ton/ha/tahun terjadi pada unit lahan 10 (budidaya sayur mayur lahan kering). Dilihat dari erosi total, erosi yang terjadi di lokasi penelitian yaitu dari 73,5 ton/tahun sampai dengan 15.672,6 ton/tahun. Erosi terbesar sebesar 15.672,6 ton/tahun terjadi pada unit lahan 10 (budidaya sayur mayur lahan kering) dan erosi terkecil sebesar 73,5 ton/tahun terjadi pada unit lahan 16 (hutan dengan serasah rendah) seperti Tabel 5.3. Hal ini menunjukkan bahwa tindakan konservasi tanah dan air aktual di lokasi penelitian kurang memadai sehingga perlu ditingkatkan terutama pada unit lahan 6 , $8,10,11,13$, dan 14. Upaya konservasi tanah dan air dikatakan memadai bilamana erosi yang terjadi minimal sama dan/atau lebih kecil dari erosi yang dapat ditoleransikan (EDT).

Tabel 3. Erosi di lokasi penelitian

\begin{tabular}{clrrrr}
\hline \multirow{2}{*}{$\begin{array}{c}\text { Unit } \\
\text { lahan }\end{array}$} & \multicolumn{1}{c}{ Penggunaan Lahan } & \multicolumn{2}{c}{ Erosi } & \multicolumn{2}{c}{ EDT } \\
\cline { 3 - 6 } & Budidaya sayur mayur lahan kering & 8,4 & $1.446,8$ & 8,4 & $1.446,8$ \\
tahun) & (ton/tahun) & $\begin{array}{c}\text { (ton/ha/ } \\
\text { tahun) }\end{array}$ & (ton/tahun) \\
\hline 2 & Budidaya sayur mayur lahan kering & 11,4 & 66,6 & 11,4 & 66,6 \\
3 & Budidaya sayur mayur lahan kering & 16,3 & $3.979,3$ & 16,3 & $3.979,3$ \\
4 & 28,6 & 547,6 & 28,6 & 547,6 \\
5 & Budidaya sayur mayur lahan kering & 195,4 & $5.586,6$ & 30,5 & 870,7 \\
6 & Budidaya sayur mayur lahan kering & 297,8 & $5.920,4$ & 30,8 & 612,2 \\
8 & Budidaya sayur mayur lahan kering & 670,3 & $15.672,6$ & 29,7 & 693,7 \\
10 & Budidaya sayur mayur lahan kering & 337,7 & $8.578,3$ & 33,7 & 857,0 \\
11 & Pertanaman kopi & 62,9 & $1.888,1$ & 31,2 & 935,1 \\
13 & Semak belukar & 88,1 & $1.141,9$ & 33,4 & 432,4 \\
14 & Semak belukar & 3,1 & 73,5 & 3,1 & 73,5 \\
16 & Hutan dengan serasah rendah & 23,8 & 201,5 & 23,8 & 201,5 \\
19 & Hutan dengan serasah rendah & 2,1 & 175,5 & 2,1 & 175,5 \\
20 & Hutan dengan serasah rendah & 6,3 & 600,7 & 6,3 & 600,7 \\
21 & Hutan dengan serasah rendah & 4,4 & 183,0 & 4,4 & 183,0 \\
22 & Hutan dengan serasah rendah & 6,5 & $1.416,5$ & 6,5 & $1.416,5$ \\
23 & Hutan dengan serasah rendah & 8,9 & 327,2 & 8,9 & 327,2 \\
24 & Hutan dengan serasah rendah & 9,3 & $8.029,6$ & 9,3 & $8.029,6$ \\
25 & Hutan dengan serasah rendah & & $55.835,5$ & & $21.448,8$ \\
\hline Jumlahy & & & & &
\end{tabular}

Sumber: Adnyana (2006) dan hasil analisis

Peningkatan teknik konservasi tanah dan air dari teras bangku berkonstruksi buruk menjadi penanaman menurut kontur kemiringan $>20 \%$, teras bangku konstruksi baik, dan pemberian mulsa 6 ton/ha pada unit lahan 6 berdampak positif terhadap penurunan erosi yang lebih kecil dibandingkan EDT, yaitu sebesar 297,8 ton/ta/tahun seperti Tabel 3 menjadi 17,6 ton/ha/tahun seperti
Tabel 4. Erosi sebesar 337,7 ton/ha/tahun pada unit lahan 11 seperti Tabel 3 dapat ditekan menjadi 16,9 ton/ha/tahun yang lebih kecil dibandingkan EDT melalui peningkatanteknik konservasi tanah dan air dari teras tradisional menjadi teras berkonstruksi baik yang dikombinasikan dengan pemberian mulsa 3 ton/haseperti Tabel 4. 
Tabel 4. Erosi Setelah Penerapan Konservasi Tanah dan Air

\begin{tabular}{|c|c|c|c|c|}
\hline \multirow{2}{*}{$\begin{array}{l}\text { Unit } \\
\text { lahan }\end{array}$} & \multirow{2}{*}{ Penggunaan lahan dan teknik konservasi } & \multirow{2}{*}{$\begin{array}{c}\text { Luas } \\
\text { (ha) }\end{array}$} & \multicolumn{2}{|c|}{ Erosi } \\
\hline & & & (ton/ha/tahun) & (ton/ tahun) \\
\hline 2 & $\begin{array}{l}\text { Budidaya sayur mayur lahan kering berteras bangku } \\
\text { konstruksi sedang }\end{array}$ & 171,7 & 8,4 & $1.446,8$ \\
\hline 3 & $\begin{array}{l}\text { Budidaya sayur mayur lahan kering berteras bangku } \\
\text { konstruksi sedang }\end{array}$ & 5,8 & 11,4 & 66,6 \\
\hline 4 & $\begin{array}{l}\text { Budidaya sayur mayur lahan kering berteras bangku } \\
\text { konstruksi sedang }\end{array}$ & 243,6 & 16,3 & $3.979,3$ \\
\hline 5 & $\begin{array}{l}\text { Budidaya sayur mayur lahan kering berteras bangku } \\
\text { konstruksi buruk }\end{array}$ & 19,2 & 28,6 & 547,6 \\
\hline 6 & $\begin{array}{l}\text { Budidaya sayur mayur lahan kering, penanaman menurut } \\
\text { kontur kemiringan 9-20\%, strip rumput, dan pemberian } \\
\text { mulsa } 6 \text { ton/ha }\end{array}$ & 28,6 & 17,6 & 502,8 \\
\hline 8 & $\begin{array}{l}\text { Budidaya sayur mayur lahan kering, penanaman menurut } \\
\text { kontur kemiringan }>20 \% \text {, teras bangku konstruksi baik, } \\
\text { dan pemberian mulsa } 6 \text { ton/ha }\end{array}$ & 19,9 & 9,2 & 182,7 \\
\hline 10 & $\begin{array}{l}\text { Budidaya sayur mayur lahan kering, penanaman menurut } \\
\text { kontur kemiringan }>20 \% \text {, teras bangku konstruksi baik, dan } \\
\text { pemberian mulsa } 6 \text { ton/ha }\end{array}$ & 23,4 & 20,7 & 483,6 \\
\hline 11 & $\begin{array}{l}\text { Pertanaman kopi, teras bangku baik, dan pemberian mulsa } \\
3 \text { ton/ha }\end{array}$ & 25,4 & 16,9 & 428,9 \\
\hline 13 & Hutan alami dengan serasah sedang (suksesi alami) & 30,0 & 2,6 & 78,7 \\
\hline 14 & Hutan alami dengan serasah sedang (suksesi alami) & 13,0 & 3,7 & 47,6 \\
\hline 16 & Hutan dengan serasah sedang & 23,6 & 3,1 & 73,5 \\
\hline 19 & Hutan dengan serasah sedang & 8,5 & 23,8 & 201,5 \\
\hline 20 & Hutan dengan serasah sedang & 82,5 & 2,1 & 175,5 \\
\hline 21 & Hutan dengan serasah sedang & 94,4 & 6,4 & 600,7 \\
\hline 22 & Hutan dengan serasah sedang & 41,2 & 4,5 & 183,0 \\
\hline 23 & Hutan dengan serasah sedang & 216,9 & 6,5 & $1.416,6$ \\
\hline 24 & Hutan dengan serasah sedang & 36,9 & 8,9 & 327,2 \\
\hline 25 & Hutan dengan serasah sedang & 859,4 & 9,3 & $8.029,6$ \\
\hline & Jumlah & $1.943,8$ & & $18.772,0$ \\
\hline
\end{tabular}

Sumber: Adnyana (2006) dan hasil analisis

Teknik konservasi tanah dan air seperti Tabel 4 sangat efektif dalam menekan hasil sedimen DTA Danau Buyan. Penggunaan lahan dengan teknik konservasi tanah dan air yang memadai secara nyata dapat menurunkan besaran erosi menjadi lebih kecil dibandingkan EDT. Penurunan besaran erosi total akan berdampak penting terhadap penurunan hasil sedimen di DTA Danau Buyan. Dilihat dari luas DTA Danau Buyan yaitu seluas 1.943,8 Ha dengan nilai SDR sebesar 16,8\% (Boyce, 1975), hasil sedimen yang terjadi berturut-turut sebesar 9.399,4 ton/tahun berdasarkan erosi total aktual, 3.610,7 ton/ha berdasarkan EDT, dan 3.160,1 ton/tahun berdasarkan erosi total setelah penerapan konservasi tanah dan air yang memadai.
Sebagai interaksi antara erosi total dan SDR, penurunan hasil sedimen akan berdampak langsung terhadap jumlah kehilangan unsur hara tanah. Kehilangan C-organik dan unsur hara tanah di lokasi penelitian diprediksi dengan mengkonversikan kandungan $\mathrm{C}$ organik dan unsur hara tanah hasil analisis laboratorium berdasarkan hasil sedimen per satuan luas yang terjadi di DTA Danau Buyan.

Rerata kandungan C-organik dan unsur hara tanah di lokasi penelitianberturut-turut adalah sebesar 2,84\% (sedang) untuk kandungan $\mathrm{C}$ organik tanah; $0,15 \%$ (rendah) untuk $\mathrm{N}$ total; 168,11 ppm (sangat tinggi) untuk P-tersedia; dan 624,38 ppm (sangat tinggi) untuk K-tersedia seperti Tabel 5. 
Tabel 5. Kandungan C-organik dan unsur hara tanah di lokasi penelitian

\begin{tabular}{|c|c|c|c|c|c|c|c|c|c|c|c|}
\hline \multirow{3}{*}{$\begin{array}{c}\text { No. } \\
1\end{array}$} & \multicolumn{3}{|c|}{ Sampel } & \multirow{2}{*}{\multicolumn{2}{|c|}{$\begin{array}{c}\text { C-organik } \\
(\%)\end{array}$}} & \multirow{2}{*}{\multicolumn{2}{|c|}{$\begin{array}{c}\text { N-total } \\
(\%)\end{array}$}} & \multirow{2}{*}{\multicolumn{2}{|c|}{$\begin{array}{c}\text { P-tersedia } \\
\text { (ppm) }\end{array}$}} & \multirow{2}{*}{\multicolumn{2}{|c|}{$\begin{array}{c}\text { K-tersedia } \\
(\text { ppm) }\end{array}$}} \\
\hline & \multirow{2}{*}{$\begin{array}{c}\text { Kode } \\
\text { ST1 }\end{array}$} & \multirow{2}{*}{$\begin{array}{c}\text { Lintang } \\
295320\end{array}$} & \multirow{2}{*}{$\begin{array}{c}\text { Bujur } \\
9088648\end{array}$} & & & & & & & & \\
\hline & & & & 2,10 & $\mathrm{~S}$ & 0,15 & $\mathrm{R}$ & 16,57 & $\mathrm{~S}$ & 195,43 & $\mathrm{~S}$ \\
\hline 2 & ST2 & 295699 & 9088466 & 3,10 & $\mathrm{~T}$ & 0,13 & $\mathrm{R}$ & 41,03 & ST & 242,69 & $\mathrm{~T}$ \\
\hline 3 & ST3 & 296547 & 9086973 & 2,83 & $\mathrm{~S}$ & 0,18 & $\mathrm{R}$ & 209,56 & ST & 238,72 & $\mathrm{~T}$ \\
\hline 4 & ST4 & 296651 & 9086731 & 3,02 & $\mathrm{~T}$ & 0,16 & $\mathrm{R}$ & 187,33 & ST & 197,37 & $\mathrm{~S}$ \\
\hline 5 & ST5 & 296347 & 9086954 & 2,27 & $\mathrm{~S}$ & 0,15 & $\mathrm{R}$ & 28,23 & $\mathrm{~T}$ & 248,80 & $\mathrm{~T}$ \\
\hline 6 & ST6 & 295261 & 9087135 & 2,48 & $\mathrm{~S}$ & 0,15 & $\mathrm{R}$ & 455,55 & ST & $3.657,90$ & ST \\
\hline 7 & ST7 & 292823 & 9086939 & 4,16 & $\mathrm{~T}$ & 0,18 & $\mathrm{R}$ & 18,63 & $\mathrm{~S}$ & 407,18 & ST \\
\hline 8 & ST8 & 294231 & 9087295 & 3,84 & $\mathrm{~T}$ & 0,18 & $\mathrm{R}$ & 26,95 & $\mathrm{~T}$ & 363,89 & $\mathrm{~T}$ \\
\hline 9 & ST9 & 294735 & 9087375 & 2,59 & $\mathrm{~S}$ & 0,15 & $\mathrm{R}$ & 242,78 & ST & 443,88 & ST \\
\hline 10 & ST10 & 294923 & 9087544 & 2,42 & $\mathrm{~S}$ & 0,10 & $\mathrm{R}$ & 247,33 & ST & 495,16 & ST \\
\hline 11 & ST11 & 295183 & 9087410 & 3,18 & $\mathrm{~T}$ & 0,23 & $\mathrm{~S}$ & 270,84 & ST & 685,90 & ST \\
\hline 12 & ST12 & 295922 & 9087660 & 2,05 & $\mathrm{~S}$ & 0,09 & $\mathrm{R}$ & 272,50 & ST & 315,63 & $\mathrm{~T}$ \\
\hline & Rerata & & & 2,84 & $\mathrm{~S}$ & 0,15 & $\mathrm{R}$ & 168,11 & ST & 624,38 & ST \\
\hline & & & & 017) & & & & & & & \\
\hline $\mathrm{K}$ & gan & Kriteri & tanal & edo & & & & 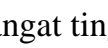 & & $=$ ren & \\
\hline
\end{tabular}

Kehilangan kandungan C-organik dan unsur hara tanah di lokasi penelitian adalah berturut-turut sebesar 266,6 ton/tahun untuk C-organik; 14,5 ton/tahun untuk N-total; 15,8 ton/tahun untuk P-tersedia; dan 58,7 ton/tahun untuk K-tersedia. Kehilangan kandungan C-organik dan unsur hara tersebut dapat ditekan melalui penerapan konservasi tanah dan air yang memadai menjadi sebesar 89,6 ton/tahun untuk Corganik; 4,9 ton/tahun untuk N-total; 5,3 ton/tahun untuk P-tersedia; dan 19,7 ton/tahun untuk K-tersedia seperti Tabel 6.

Tabel 6. Kehilangan kandungan C-organik dan unsur hara tanah di lokasi penelitian

\begin{tabular}{|c|c|c|c|c|c|c|}
\hline \multirow[b]{2}{*}{ No. } & \multirow[b]{2}{*}{ Erosi (ton/tahun) } & \multirow{2}{*}{$\begin{array}{c}\text { Hasil sedimen } \\
\text { (ton/tahun) }\end{array}$} & \multicolumn{4}{|c|}{ Kehilangan C-organik dan unsur hara tanah (ton/tahun) } \\
\hline & & & C-organik & N-total & P-tersedia & K-tersedia \\
\hline A & $\begin{array}{l}\text { Konservasi aktual } \\
55.835,5\end{array}$ & $9.399,4$ & 266,6 & 14,5 & 15,8 & 58,7 \\
\hline B & Erosi yang dapat ditol & nsikan & & & & \\
\hline & $21.448,8$ & $3.610,7$ & 102,4 & 5,6 & 6,1 & 22,6 \\
\hline $\mathrm{C}$ & Penerapan konservas & tah dan air yang $\mathrm{m}$ & & & & \\
\hline & $18.772,0$ & $3.160,1$ & 89,6 & 4,9 & 5,3 & 19,7 \\
\hline
\end{tabular}

Sumber: Hasil analisis

\subsection{Status Trofik Perairan Danau Buyan}

Status trofik perairan Danau Buyan ditetapkan berdasarkan kriteriaPeraturan Menteri Lingkungan Hidup Nomor 28 tahun 2009 dan TSI Carlson yang ditetapkan dengan persamaan (4). Stasiun 1, 2, dan 3 adalah stasiun pengambilan sampel yang dipengaruhi langsung aliran masuk ke perairan danau, dan stasiun 4 dan 5 adalah stasiun kontrol.

Rerata total nitrogen (TN), TP, klorofil a, kecerahan, rasio $\mathrm{TN}$ dan $\mathrm{TP}$, dan TSI perairan Danau Buyan berturut- turut adalah sebesar $3.500 \mu \mathrm{g} / \mathrm{L} ; 118,4$ $\mu \mathrm{g} / \mathrm{L} ; 48,2 \mu \mathrm{g} / \mathrm{L} ; 1,8 \mathrm{~m} ; 29,6$; dan 64,3 seperti Tabel 7. Kandungan variabel status trofik seperti Tabel 7 dan Gambar 1 pada semua stasiun pengambilan sampel cenderung merata dan mengindikasikan perairan Danau Buyan telah mengalami peningkatan kesuburan yang berpotensi sebagai ancaman terhadap keberlanjutan multifungsi danau. Status trofik Danau Buyan menurut kriteria Peraturan Menteri Lingkungan Hidup Nomor 28 tahun 2009 tergolong eutrof sampai hypereutrof, hypereutrof menurut rasio 
TN dan TP, dan eutrofik sedang menurut indeks status trofik Carlson.

Nilai TN dan TP yang tinggi di semua stasiun sampling seperti Tabel 7 mengindikasikan input $\mathrm{N}$ dan $\mathrm{P}$ yang relatif besar dari DTA Danau Buyan ke perairan danau. $\mathrm{N}$ dan $\mathrm{P}$ diperkirakan bersumber dari erosi dan kegiatan pertanian di DTA yang masuk ke danau melalui aliran sungai, budidaya ikan dalam karamba jaring apung (KJA), dan dekomposisi bahan organik.

Erosi di DTA Danau Buyan berpotensi memberikan input $\mathrm{N}$ dan $\mathrm{P}$ ke perairan danau masing-masing sebesar 14,5 dan 15,8 ton/tahun seperti Tabel 6 melalui masuknya sedimen ke perairan danau. Sedimentasi yang terjadi pada sungai yang bermuara ke stasiun pengambilan sampel dapat diduga berkontribusi besar terhadap peningkatan kandungan TN dan TP perairan Danau Buyan.

Kegiatan pertanian di DTA Danau Buyan juga berkontribusi besar terhadap input $\mathrm{N}$ dan $\mathrm{P}$ ke perairan danau melalui sistem draenase. Pupuk yang digunakan pada lahan pertanian masuk ke aliran sungai dan bermuara ke perairan danau (Frame dan Mark, 2013). Agustiningsih (2012) menyatakan bahwa pupuk yang terlimpas ke sungai dan waduk mencapai $70 \%$ dan hanya $30 \%$ saja yang terserap akar tanaman. Dilihat dari keterjangkaun harga dan ketersediaan pasar, petani di lokasi penelitian cenderung mengaplikasikan pupuk urea, ZA, dan SP36 dalam kegiatan budidaya sayur mayur. Kandungan N yang mencapai 46\% dalam pupuk urea (Saragih et al., 2013) dan $21 \%$ pada pupuk ZA (BSNI, 2005), dan kandungan $\mathrm{P}$ pupuk SP36 sebesar 36\% (Kasno, 2009).
Budidaya ikan KJA dapat diduga berkontribusi terhadap asupan $\mathrm{N}$ dan $\mathrm{P}$ di perairan Danau Buyan. Pengkayaan nitrat $\left(\mathrm{NO}_{3}\right)$ dalam badan air dapat disebabkan input pakan pada kegiatan budidaya ikan KJA (Ginting, 2011 dalam Saputra et al., 2016). Budidaya ikan KJA berkontribusi terhadap kandungan $\mathrm{N}$ dan $\mathrm{P}$ perairan dalam bentuk sisa pakan, feses ikan, dan limbah metabolik ikan berupa ammonia dan urea. $\mathrm{N}$ yang dilepaskan ke lingkungan dari sisa pakan ikan mencapai $68-86 \%$ dan $71,4 \%$ untuk $\mathrm{P}$ (Price dan Morris JA, 2013).

Sumber $\mathrm{N}$ dan $\mathrm{P}$ perairan Danau Buyan sangat dimungkinkan berasal dari dekomposisi bahan organik (tumbuhan dan biota perairan yang telah mati). Tumbuhan air kiambang (Salvinia molesta) yang tumbuh luas di perairan Danau Buyan memiliki kandungan $\mathrm{N}$ dan $P$ yang tinggi bila membusuk (Saputra et al., 2016). Kandungan N dan $\mathrm{P}$ kiambang pada daun sebesar 0,216 $\mathrm{mg} / \mathrm{L}$ dan $0,054 \mathrm{mg} / \mathrm{L}$, dan pada akar sebesar $0,073 \mathrm{mg} / \mathrm{L}$ dan $0,021 \mathrm{mg} / \mathrm{L}$ (Angga et al., 2010 dalam Saputra et al., 2016). Kecepatan arus perairan Danau Buyan yang relatif sedang (Saputra et al., 2016) dan mobilisasi tumbuhan air kiambangberpotensi memberikan pengaruh yang relatif besar terhadap distribusi TN dan TP. Mobilisasi tumbuhan air kiambang yang menumpuk pada sisi timur danau pada bulan September-Desember dan sisi barat pada bulan Januari-Agustus dapat diduga berdampak penting terhadap distribusi kandungan hara di perairan Danau Buyan. 
Tabel 5.7. Status Trofik Danau Buyan menurut Kriteria Status Trofik Danau, Rasio Total Nitrogen dan Total Fosfat, dan Indeks Status Danau Carlson

\begin{tabular}{|c|c|c|c|c|c|c|c|c|c|}
\hline \multicolumn{3}{|c|}{ Sampel } & \multicolumn{7}{|c|}{ Status trofik danau menurut kriteria status trofik ${ }^{1)}$} \\
\hline Kode & Lintang & Bujur & \multicolumn{3}{|c|}{ Total nitrogen $(\mu \mathrm{g} / \mathrm{L})$} & \multicolumn{2}{|c|}{ Total fosfat $(\mu \mathrm{g} / \mathrm{L})$} & Klorofil a $(\mu \mathrm{g} / \mathrm{L})$ & Kecerahan \\
\hline SA1 & 294736 & 9088412 & 4.200 & \multicolumn{2}{|c|}{$\begin{array}{l}\text { hiper- } \\
\text { eutrofik }\end{array}$} & \multicolumn{2}{|c|}{125 hiper- } & 51 eutrof & 1,8 \\
\hline SA2 & 293878 & 9087933 & 2.100 & \multicolumn{2}{|c|}{$\begin{array}{l}\text { hiper- } \\
\text { eutrofik }\end{array}$} & \multicolumn{2}{|l|}{102} & eutrof & 1,9 \\
\hline SA3 & 292816 & 9087830 & 2.800 & \multicolumn{2}{|c|}{$\begin{array}{l}\text { hiper- } \\
\text { eutrofik }\end{array}$} & \multicolumn{2}{|l|}{120} & eutrof & 1,8 \\
\hline SA4 & 291933 & 9088183 & 3.500 & \multicolumn{2}{|c|}{$\begin{array}{l}\text { hiper- } \\
\text { eutrofik }\end{array}$} & 134 & $\begin{array}{l}\text { hiper- } \\
\text { eutrofik }\end{array}$ & eutrof & 1,8 \\
\hline SA5 & 293274 & 9088399 & 4.900 & \multicolumn{2}{|c|}{$\begin{array}{l}\text { hiper- } \\
\text { eutrofik }\end{array}$} & 111 & $\begin{array}{l}\text { hiper- } \\
\text { eutrofik }\end{array}$ & eutrof & 1,8 \\
\hline Rerata & & & 3.500 & \multicolumn{2}{|c|}{$\begin{array}{l}\text { hiper- } \\
\text { eutrofik }\end{array}$} & 118,4 & $\begin{array}{l}\text { hiper- } \\
\text { eutrofik }\end{array}$ & eutrof & 1,8 \\
\hline \multirow{2}{*}{\multicolumn{3}{|c|}{$\begin{array}{l}\text { Rasio total nitrogen dan total } \\
\text { fosfat }^{2)}\end{array}$}} & \multicolumn{7}{|c|}{ Status trofik danau menurut Carlson ${ }^{3)}$} \\
\hline & & & \multirow{2}{*}{\multicolumn{2}{|c|}{$\begin{array}{r}\text { TSI-P } \\
73,8\end{array}$}} & TSI-C & TSI- & TSI & \multicolumn{2}{|c|}{ Status trofik } \\
\hline 33,6 & \multicolumn{2}{|c|}{ fosfat pembatas trofik } & & & 69,2 & 51 & 64,8 & \multicolumn{2}{|l|}{ eutrofik sedang } \\
\hline 20,6 & \multicolumn{2}{|c|}{ fosfat pembatas trofik } & & 0,8 & 68,2 & 51 & 63,4 & \multicolumn{2}{|l|}{ eutrofik sedang } \\
\hline 23,3 & \multicolumn{2}{|c|}{ fosfat pembatas trofik } & & 3,2 & 68,6 & 51 & 64,4 & \multicolumn{2}{|l|}{ eutrofik sedang } \\
\hline 26,1 & \multicolumn{2}{|c|}{ fosfat pembatas trofik } & & 4,8 & 69,0 & 51 & 65,1 & \multicolumn{2}{|l|}{ eutrofik sedang } \\
\hline 44,1 & \multicolumn{2}{|c|}{ fosfat pembatas trofik } & & 2,1 & 68,2 & 51 & 63,9 & \multicolumn{2}{|l|}{ eutrofik sedang } \\
\hline 29,6 & \multicolumn{2}{|c|}{ fosfat pembatas trofik } & & 3,0 & 68,6 & 51 & 64,3 & \multicolumn{2}{|l|}{ eutrofik sedang } \\
\hline
\end{tabular}

Sumber : Total nitrogen dianalisis di Laboratorium Ilmu Tanah Fakultas Pertanian, total fosfat dan klorofil a dianalisis di UPT Laboratorium Analitik Universitas Udayana, dan kecerahan diukur secara in situ (2017)

Keterangan :

1) Kriteria status trofik danau menurut Peraturan Menteri Negara Lingkungan Hidup Nomor 28 Tahun 2009 tentang Daya Tampung Beban Pencemaran Air Danau dan/atau Waduk (Kementerian Lingkungan Hidup, 2009) sesuai Tabel 2.2.

2) Total nitrogen : total fosfat $>12$ (fosfat pembatas trofik); total nitrogen : total fosfat $<7$ (nitrogen pembatas trofik; dan $7<$ total nitrogen : total fosfat $<12$ (fosfat dan nitrogen tidak pembatas trofik) (Beveridge, 1984 dan Horne dan Goldman, 1994).

3) TSI-P (indeks status trofik total fosfat), TSI-C (indeks status trofik klorofil a), TSI-S (indeks status trofik kecerahan), dan TSI (indeks status trofik Carlson) sesuai persamaan (2.6). 


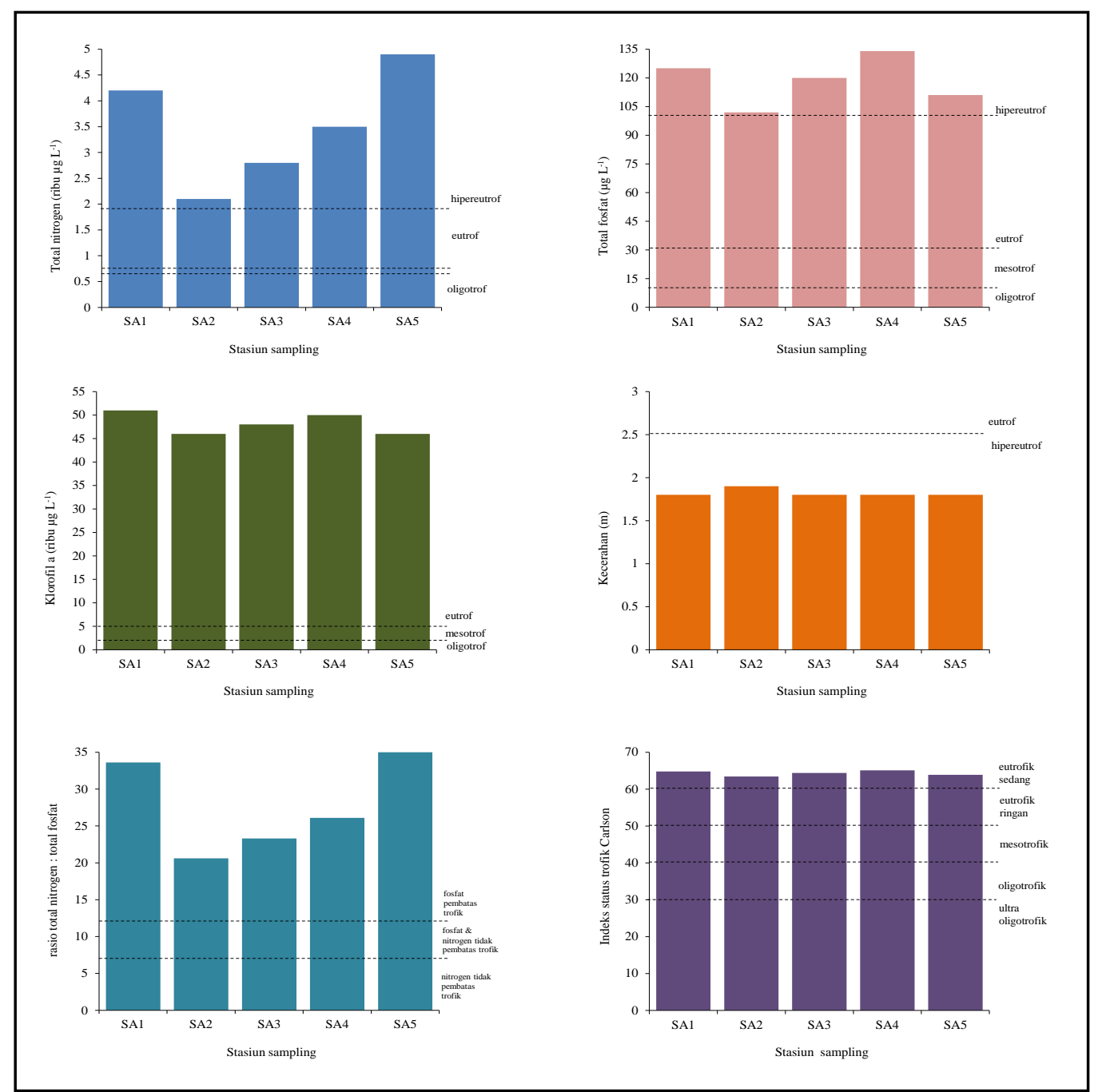

Gambar 1.

Status Trofik Danau Buyan

Dilihat dari hasil penelitian terhadap dekomposisi tumbuhan air kiambang (Angga et el., 2010 dalam Saputra et al., 2016) dan studi kinetis senyawa $\mathrm{N}$ dan $\mathrm{P}$ dari resuspensi sedimen skala laboratorium (Prartono dan Hasena, 2009), kegiatan pengerukan dapat juga diduga sebagai pencetus terjadinya peningkatan hara di perairan Danau Buyan. Studi kinetis senyawa N dan P dari resuspensi sedimen skala laboratorium menunjukkan bahwa dengan pengadukan sedimen dalam air laut dengan kecepatan $1 \mathrm{~m} /$ detik dan dalam 5 menit, peningkatan nutrisi sebagai indikasi pelepasan senyawa dalam air menunjukkan rerata nutrisi per gram sedimen mencapai 1,8 $\mu \mathrm{g}$ P, 292 $\mu \mathrm{g}$ ammonia, $276 \mu \mathrm{g}$ ammonium, 1,8 $\mu \mathrm{g}$ nitrit, dan 9,1 $\mu \mathrm{g}$ nitrat.

Kandungan klorofil a hasil uji berkisar 46-51 $\mu \mathrm{g} / \mathrm{L}$ seperti Tabel 7 . Nilai klorofil a yang relatif tinggi dijumpai pada stasiun 1 dan 4 . Perairan dengan nilai klorofil a di atas 15 hingga $<200 \mu \mathrm{g} / \mathrm{L}$ dikategorikan dalam status eutrof (Kementerian Lingkungan Hidup, 2009). Kecendrungan kandungan klorofil a yang tinggi pada stasiun 1 disebabkan pada stasiun pengambilan sampel tersebut adalah titik akumulasi masuknya hara $\mathrm{N}$ dan $\mathrm{P}$ ke perairan 
Danau Buyan. Kandungan klorofil a yang tinggi pada stasiun 4 cenderung disebabkan tingginya kandungan $\mathrm{P}$ pada stasiun pengambilan sampel tersebut.Peningkatan kandungan $\mathrm{P}$ cenderung akan diikuti peningkatan kandungan klorofil a (Susanti, et al., 2012).

Kecerahan pada semua stasiun pengambilan sampel seperti Tabel 7 memiliki kedalaman kurang dari $2 \mathrm{~m}$. Nilai kecerahan berkisar antara 1,8 sampai 1,9 m mengindikasikan telah terjadi peningkatan kesuburan perairan Danau Buyan. Kisaran nilai kecerahan perairan 0,5 hingga $4,2 \quad \mathrm{~m}$ mengindikasikan telah terjadinya penyuburan perairan Danau Limboto yang relatif cepat (Suryono et al., 2008).

\section{SIMPULAN DAN SARAN}

\subsection{Simpulan}

1) Penggunaan lahan di DTA Danau Buyan didominasi hutan alami dengan serasah sedang, diikuti budidaya sayur mayur lahan kering, dan penggunaan lahan terkecil berupa pertanaman kopi. Aktivitas penggunaan lahan di DTA Danau Buyan yang berdampak penting terhadap degradasi lahan dan eutrofikasi adalah budidaya sayur mayur lahan kering dengan pengolahan tanah yang masih konvensional (olah tanah sempurna), penanaman pada petak teras bangku searah lereng pada musim hujan, penggunaan pupuk, pestisida, dan insektisida anorganik yang masih relatif tinggi, dan pengelolaan sisa tanaman yang belum memenuhi kaidah konservasi tanah dan air.

2) Hasil sedimen dan kehilangan hara aktual di DTA Danau Buyan tiga kali lebih besar dibandingkan hasil sedimen dan kehilangan hara dengan penerapan konservasi tanah dan air yang sesuai dengan kaidah keberlanjutan sumberdaya lahan dan air. Hasil sedimen dan kehilangan hara sangat berpotensi mengakibatkan terjadinya peningkatan kesuburan perairan karena Danau Buyan adalah titik akhir dari sistem aliran permukaan DTA Danau Buyan.

3) Pengujian parameter status trofik danau terhadap sampel air permukaan Danau Buyan menunjukkan status trofik danau tergolong eutrof sampai dengan hypereutrof menurut kriteria Peraturan Menteri Negara Lingkungan Hidup Nomor 28 Tahun 2009 dan tergolong eutrofik sedang menurut indeks status trofik Carlson.

\subsection{Saran}

1) Tindakan konservasi tanah dan air melalui pendekatan mekanis dan vegetatif di lokasi penelitian perlu ditingkatkan sebagai upaya menekan laju erosi yang berpotensi mempercepat terjadinya degradasi lahan.

2) Hasil sedimen dan besaran kehilangan hara yang terjadi di DTA Danau Buyan dapat dikelola melalui penerapan konservasi tanah dan air yang sesuai dengan kaidah keberlanjutan sumberdaya lahan dan air.

3) Status trofik perairan Danau Buyan yang tergolong eutrofik sampai hypereutofik mengharuskan segera dilakukannya pengelolaan pada lahan pertanian dan ekosistem perairan yang diikuti dengan penelitian lanjutan untuk menetapkan tingkat ancaman terhadap keberlanjutan multifungsi 
danau. Pengelolaan pada lahan pertanian dilakukan melalui upaya peningkatan tindakan konservasi tanah dan air, pengurangan pemakaian pupuk anorganik, dan peningkatan pemakaian pupuk organik. Pengelolaan pada ekosistem perairan dilakukan melalui pemanenan kiambang dan eceng gondok dan pembersihan sedimen melalui penyedotan, dan budidaya ikan dalam KJA yang disesuaikan daya dukung perairan danau.

\section{DAFTAR PUSTAKA}

Adnyana, I Wayan Sandi, Fumihiko Nsihio, Josaphat Tetuko Sri Sumantyo, dan Gede Hendrawan. 2006. Monitoringof Land Use Changes Using Aerial Photograph and Ikonos Image in Bedugul, Bali. International Journal of Remote Sensing and Earth Sciences Volume 3 September 2006. p 51-58.

Adnyana, I Wayan Sandi. 2009. Peranan Konservasi Tanah dan Air pada Pengelolaan Daerah Aliran Sungai. Orasi ilmiah Pidao Pengukuran Guru Besar Tetap dalam Bidang Konservasi Tanah dan Air pada Program Studi Agroekoteknologi Fakultas Pertanian Universitas Udayana Sabtu, 21 Februari 2009. Denpasar: Universitas Udayana.

Agustiningsih. 2012. Kajian Kualitas Air Sungai Blukar Kabupaten Kendal dalam Upaya Pengendalian Pencemaran Sungai (tesis). Available from URL: https://eprint.undip.ac.id(dikutip 15 Pebruari 2018).
Asdak, Chay. 1995. Hidrologi dan Pengelolaan Daerah Aliran Sungai. Yogyakarta: Gajah Mada University Press.

Ariska, Netty Dwi, Neneg Laela Nurida, dan Zaenal Kusuma. 2016. Pengaruh Olah Tanah Konservasi Terhadap Retensi Air dan Ketanahanan Penetrasi Tanah pada Lahan Kering Masam di Lampung Timur. Jurnal Tanah dan Sumberdaya Lahan Volume 3 (1). Available from URL: https://jtsl.ub.ac.id(dikutip $\quad 15$ Pebruari 2018).

Badan Standardisasi Nasional. 2005. SNI 02-1760-2005: Pupuk Amonium Sulfat. Available from URL: http://klh.solokkota.go.id(dikutip 10 Pebruari 2018).

Biro Humas Sekretariat Provinsi Bali. 2015. Gelar Gerdasih, Gubernur Pastika Ajak Masyarakat PeduliKelestarian Danau. Available from URL: http://birohumas.baliprov.go.id tanggal 14 April 2015 (dikutip 14 April 2016).

Boyce, Robert C. 1975. Sediment Routing With Sediment Delivery Ratios. In Present and Prospective Technology for Predicting Sediment Yields and Sources. United States Department of Agriculture Soil Conservation Service. Available from URL: http://directives.sc.egov.usda.gov (dikutip 14 Nopember 2017).

Boyd, Claude E. dan Frank Lichtkoppler. 1979. Water Quality Management in Pond Fish 
Culture. Research and Development Series No. 22 Project : AID/DSAN-G 0039 April 1979. Available from URL: http://aurora.auburn.edu (dikutip 22 Nopember 2017).

Carlson, Robert E. 1977. A Trophic State Index for Lakes. Available from URL: http://www.owrb.ok.gov (dikutip 11 Nopember 2017).

Faizal, Cyndi S., Meldi Sinolungan, Zetly Tamod, dan Tommy Sondakh. 2013. Erosi pada Lahan Hortikultura yang Ditanami Wortel (Daucus carrota L.) di Kelurahan Rurukan Kecamatan Tomohon Timur. Available from URL : http://www.ejournal.unsrat.ac.id (dikutip 14 Mei 2018).

Frame Hunter dan Mark S Reiter. 2013. Enhanced Efficiency Fertilizer Materials: Nitrogen Stabilizer. Publication CSES-52P. Available from URL: http://www.ext.vt.edu (dikutip 10 Januari 2018).

H, Henny, K.Murtilaksono, N. Sinukaban, dan SD Tarigan. 2011. Erosi dan Kehilangan Hara pada Pertanaman Kentang dengan Beberapa Sistem Guludan pada Andisol di Hulu DAS Merao, Kabupaten Kerinci, Jambi. Jurnal Solum Volume 8 (2) Juli 2011. Available from URL: http:// jurnalsolum.faperta.unand.ac.id (dikutip 18 Januari 2018).

Heryani, Nani, Budi Kartiwa, Yon Sugiarto, dan Tri Handayani. 2013. Pemberian Mulsa dalam Budidaya Cabai Rawit di Lahan Kering: Dampaknya terhadap
Hasil Tanaman dan Aliran Permukaan. Jurnal Agronomi Indonesia Volume $41 \quad$ (2). Available from URL: http://journal.ipb.ac.id (dikutip 13 Januari 2017).

Jonsson, Hakan. 1997. Assesment of Sanitation Systems and Reuse of Urine. Ecological Alternatives in Sanitation. Proceedings from Sida Sanitation Workshop Balingsholm, Sweden 6-9 August 1997. Publications on Water Resources No 9. Available from URL: https:// www.ircwash.org (dikutip 15 Januari 2018)

Kasno, Antonius. 2009. Respon Tanaman Jagung terhadap Pemupukan Fosfor pada Typic Dystrudepts. Jurnal Tanah Tropika Volume 14 (2) Tahun 2009. Available from URL: http://lmedia.neliti.com (dikutip 3 Januari 2018).

Kementerian Negara Lingkungan Hidup. 2009. Peraturan Menteri Negara Lingkungan Hidup Nomor 28 Tahun 2009 tentang Daya Tampung Beban Pencemaran Air Danau dan/atau Waduk. Available from URL: http://luk.staff.ugm.ac.id (dikutip 23 September 2016).

Kementerian Lingkungan Hidup. 2008. Pedoman Pengelolaan Ekosistem Danau. Available from URL: http://www.academia.edu (dikutip 15 Juni 2016).

Manuaba, I B Putra. 2007. Cemaran Pestisida Klor-Organik dalam Air Danau Buyan Buleleng Bali. Jurnal Kimia Volume 1 (1) Juli 
2007. Available from URL: http://ojs.unud.ac.id (dikutip 15 Januari 2018).

Mara, Duncan dan Sandy Cairncross. 1994. Guidline for The Safe Use of Wastewater and Excreta in Agricultur and Aquaculture: measures for public healt protection. Geneva: World Health Organization. Available from URL: http://apps.who.int (dikutip 17 Januari 2017).

Nopiantari, Ni Putu Vivin, I Wayan Arthana, dan Ida Ayu Astarini. 2017. Dampak Kegiatan Pertanian terhadap Tingkat Eutrofikasi dan Jenis-jenis Fitoplankton di Danau Buyan Kabupaten Buleleng Provinsi Bali. Jurnal Ecotrophic Volume 11 (1) Tahun 2017. Available from URL: http://ojs.unud.ac.id (dikutip 10 Pebruari 2018).

Prartono, T dan T. Hasena. 2009. Studi Kinetis Senyawa Fosfor dan Nitrogen dari Resuspensi Sedimen. E Jurnal Ilmu dan Teknologi Kelautan Tropis Volume 1 (1) Juni 2009. Available from URL: http://www.itk.fpika. ipb.ac.id (dikutip 10 Januari 2017).

Price, Carol Seals dan James A. Morris, Jr. 2013. Marine Cage Culture and The Environment: Twenty-First Century Science Informing a Sustainable Industry. Pivers Island Rd: NOAA Technical Memorandum NOS NCCOS. Available from URL: http://www.researchgate.net (dikutip 5 Januari 2018).
Saragih D, Hamim H, Nurmauli N. 2013. Pengaruh Dosis dan Waktu Aplikasi Pupuk Urea dalam Meningkatkan Pertumbuhan dan Hasil Jagung Pioneer 27. Jurnal Agrotek Tropika. Volume 1 (1) Januari 2013. Available from URL: https://media.neliti.com (dikutip 18 Desember 2017).

Saputra, I Wayan Rian Riki, I Wayan Restu, dan Made Ayu Pratiwi. 2016. Analisis Kualitas Air Danau Sebagai Dasar Perbaikan Manajemen Budidaya Perikanan di Danau Buyan Kabupaten Buleleng, Provinsi Bali. Ecotrophic. Volume 11 (1) Tahun 2017. Available from URL: https://ojs.unud.ac.id (dikutip 11Desember 2017).

Subehi, Luki, Hendro Wibowo, dan Iwan Ridwansyah. 2014. Characteristics of Physical Catchment at Lake Buyan and Lake Tamblingan Bali Indonesia. Naskah LengkapSeminar Nasional Limnologi VII-2014: Pengelolaan Perairan Darat Berbasis Ilmu Pengetahuan untuk Menunjang Kelestarian Lingkungan dan Kesejahteraan Masyarakat. Bogor 16 September 2014. Page 358-367. Available from URL: http://limnologi.lipi.go.id(dikutip 28 Mei 2016).

Susanti, Ira Tri, Setia Budi Sasongko, dan Sudarno. 2012. Status Trofik Waduk Manggar Kota Balikpapan dan Strategi Pengelolaannya. Jurnal Presipitasi Volume 9 (2) September 2012. Available from URL: http://ejournal.undip. ac.id (dikutip 15 Januari 2018). 
Suryono, Tri, Sulung Nomosatryo, dan Endang Mulyana. 2008. Tingkat Kesuburan Danau-danau di Sumatra Barat dan Bali. Jurnal Limnotek Volume 15 (2) Tahun 2008. Available from URL: http://lipi.go.id (dikutip 15 Januari 2018).

Vinneras Bjorn. 2001. Faecal Separation and Urine Diversion for Nutrient Management of Household Biodegradable Waste and Wastewater (thesis). Uppsala: Swedish University of Agricultural Sciences. Available from URL: http://pub.epsilon.slu.se (dikutip 15 Oktober 2017).
Yangxin Yu, Jin Zhao, Andrew E Bayli. 2008. Development of surfactants and builders in detergent formulations. Chinese Journal of Chemical Engineering. Volume 16 (4) 4 September 2008. Available from URL: http://doi.org (dikutip 15 Oktober 2017).

Zulfia, Naila dan Aisyah. 2013. Status Trofik Perairan Rawa Pening Ditinjau dari Kandungan Unsur Hara $\left(\mathrm{NO}_{3}\right.$ dan $\left.\mathrm{PO}_{4}\right)$ serta Klorofila. Jurnal Bawal Volume 5 (3) Desember 2013. Available from URL://ejournalbalitbang.kkp.go.id (dikutip 18 Desember 2017). 